\title{
Defining olive ridley turtle Lepidochelys olivacea management units in Australia and assessing the potential impact of mortality in ghost nets
}

\author{
Michael P. Jensen ${ }^{1, *}$, Colin J. Limpus ${ }^{2}$, Scott D. Whiting ${ }^{3,4}$, Michael Guinea ${ }^{5}$, \\ Robert I. T. Prince ${ }^{4}$, Kiki E. M. Dethmers ${ }^{6}$, Ida Bagus Windia Adnyana ${ }^{7}$, \\ Rod Kennett ${ }^{8}$, Nancy N. FitzSimmons ${ }^{9}$ \\ ${ }^{1}$ Marine Mammal \& Turtle Division, Southwest Fisheries Science Center, National Marine Fisheries Service, NOAA, \\ 8901 La Jolla Shores Drive, La Jolla, California 92037, USA \\ ${ }^{2}$ Queensland Department of Environment and Heritage Protection (DEHP), Threatened Species Unit, \\ PO Box 2454 City, Brisbane, Queensland 4001, Australia \\ ${ }^{3}$ Department of Natural Resources, Environment, the Arts and Sport, PO Box 496, Palmerston, \\ Northern Territory 0832, Australia \\ ${ }^{4}$ Marine Science Program, Department of Parks and Wildlife (DPaW), Locked Bag 104, Bentley Delivery Centre, \\ Western Australia 6983, Australia \\ ${ }^{5}$ School of Environmental and Life Science, Faculty of Engineering, Health, Science and the Environment, \\ Charles Darwin University, Darwin, Northern Territory 0909, Australia \\ ${ }^{6}$ North Australia Marine Research Alliance, Arafura Timor Research Facility, Brinkin, Northern Territory 0810, Australia \\ ${ }^{7}$ Udayana University, FKH - UNUD, Kampus Bukit Jimbaran 8000, Bali, Indonesia \\ ${ }^{8}$ North Australian Indigenous Land and Sea Management Alliance, Charles Darwin University, \\ Northern Territory 0815, Australia \\ ${ }^{9}$ Environmental Futures Centre, Griffith University, Queensland 4222, Australia
}

\begin{abstract}
In Australia, the olive ridley sea turtle Lepidochelys olivacea has received little research attention and monitoring. The Australian populations are relatively small and their distribution is limited to remote areas in the northern part of the country. Previous global genetic studies of olive ridley populations showed that the Australian breeding population at the McCluer Group of islands, Northern Territory, is genetically distinct from other olive ridley populations breeding in the Indo-Pacific. However, nothing is known about the genetic stock structure among Australian olive ridley rookeries found across northern Australia. High predation of eggs by feral pigs, dogs and monitor lizards Varanus spp. is believed to have severely impacted the number of nesting females at some rookeries. Of particular concern is the small nesting population on the western Cape York Peninsula, and without immediate conservation action this population could face extinction. The results presented here establish that there are at least 2 independent management units (stocks) of olive ridley turtles nesting in Australia and emphasise the importance of conserving the genetically distinct small breeding population nesting along the western Cape York Peninsula. In addition, results from 44 turtles caught in ghost nets across the Gulf of Carpentaria revealed that $45 \%$ of the haplotypes (32\% of all ghost net samples) had not been observed at any rookery in Australia or SE Asia. This research highlights the need for better information on olive ridley population structure in the region and for urgent conservation action for the western Cape York population.
\end{abstract}

KEY WORDS: Genetics $\cdot$ By-catch $\cdot$ Population structure $\cdot$ Phylogeography $\cdot$ mtDNA 


\section{INTRODUCTION}

Although the olive ridley sea turtle Lepidochelys olivacea is one of the most abundant species of sea turtles in the world, it is under threat in many regions, with smaller populations in the western Pacific showing some of the strongest declining trends (Abreu-Grobois \& Plotkin 2008). This species has a circumtropical global distribution and is best known for its mass nesting events, called arribadas, which occur at only a few locations in India, Mexico and Costa Rica (Pritchard \& Plotkin 1995, Hamann et al. 2003, Plotkin 2007, Pritchard 2007a). Less is known about the populations at the numerous locations where this turtle nests in low density, often at remote beaches around the world (Pritchard \& Plotkin 1995, Bernardo \& Plotkin 2007, Plotkin 2007). This is particularly true for the western Pacific and SE Asia where information about their distribution and abundance is limited (Bernardo \& Plotkin 2007, Plotkin 2007, Pritchard 2007b). In this region, olive ridley turtles are known to nest in Myanmar and Brunei (each with $\sim 300$ nests per year; Thorbjarnarson et al. 2000), Indonesia ( 800 to 1000 nests per year; Limpus 1997, I. B. W. Adnyana \& C. Hitipeuw pers. comm.), Papua New Guinea (Ulaiwi 1997), Malaysia and Thailand (each with <50 nests per year; Chan 2001), Vietnam (tens of nests per year; Hamann et al. 2006) and Australia (few thousand females per year; Whiting et al. 2007b, Limpus 2008).

Olive ridleys used to be abundant in Myanmar, Thailand and Peninsular Malaysia, but several decades of intense egg harvest have driven this species to low numbers in most parts of the region (Limpus 1997). Olive ridley turtles generally migrate long distances and forage both in shallow coastal waters and in the open sea (Polovina et al. 2004, Morreale et al. 2007, da Silva et al. 2011). For example, olive ridley turtles are frequently caught accidently in Hawaiian longline fisheries operating in the central Pacific, thousands of kilometres from major nesting areas (Moore et al. 2009). In contrast, Australian olive ridley turtles forage over the Australian continental shelf and appear to have narrower dispersal ranges, based on bycatch data from a coastal fishery (Guinea \& Chatto 1992) and from satellite tagging of postnesting females (McMahon et al. 2007, Whiting et al. 2007a). Our knowledge of olive ridley populations and how they use the marine environment has increased recently due to additional field studies of smaller populations (da Silva et al. 2007, Whiting et al. 2007b), the application of satellite tagging (McMahon et al. 2007, Whiting et al. 2007a, da Silva et al.
2011, Maxwell et al. 2011) and genetic studies (Bowen et al. 1997, Shanker et al. 2004, López-Castro \& Rocha-Olivares 2005, Jensen et al. 2006).

For marine turtles and many other species, molecular markers have provided a rapid assessment of many aspects of population biology. They have been used extensively in marine turtle research to investigate population structure (Bowen et al. 1992, Encalada et al. 1996, Dethmers et al. 2006), the origin of turtles in mixed foraging areas (Bowen et al. 1996, Velez-Zuazo et al. 2008, Dethmers et al. 2010), global phylogeography (Bowen et al. 1992, 1997, Dutton et al. 1999), and mating systems (FitzSimmons 1998, Ireland et al. 2003, Jensen et al. 2006). In particular, the control region of the mitochondrial DNA (mtDNA) has proven useful for identifying genetic stock structure and in mixed stock analysis of foraging animals (Bowen 1995, Lee 2008). Two important applications of molecular markers that are directly relevant to the conservation and management of sea turtle species are (1) the identification of genetic stocks or management units (MUs) (Moritz 1994) and (2) the ability to determine the origin of turtles at feeding grounds, in fisheries bycatch or in harvests. (Jensen et al. 2013).

Previous genetic studies of olive ridley rookeries investigated the broader global phylogeography and historical colonisation patterns leading to the current distribution of the species and only looked at fine scale $(\leq 2000 \mathrm{~km})$ population structure in India and Mexico (Bowen et al. 1997, Shanker et al. 2004, López-Castro \& Rocha-Olivares 2005). These studies indicate that the Indo-Pacific rookeries in India, Sri Lanka, Malaysia, Australia, Mexico and Costa Rica are distinct from each other and from Atlantic populations (Bowen et al. 1997, Shanker et al. 2004). In the eastern Pacific, olive ridley turtles appear to form 1 large panmictic population with no genetic differences observed among turtles nesting in Costa Rica and several rookeries in Mexico along a coastline stretching approximately $3000 \mathrm{~km}$ (Bowen et al. 1997). However, there is some evidence of differentiation of the most northern rookeries in Baja California, Mexico (López-Castro \& Rocha-Olivares 2005). While studies of population structure within regions have rapidly advanced for other species of marine turtles in recent years, including green turtles Chelonia mydas (Chassin-Noria et al. 2004, Bass et al. 2006, Dethmers et al. 2006), hawksbill turtles Eretmochelys imbricata (Bass 1999, Browne et al. 2010, LeRoux et al. 2012), flatback turtles Natator depressus (Pittard 2010), loggerhead turtles Caretta caretta (Shamblin et al. 2011) and leatherback turtles Der- 
mochelys coriacea (Dutton et al. 2013), the finer-scale population structure of olive ridley turtles has received little attention. This lack of information is hindering not only sound management decisions for the species, but also the ability to conduct mixed-stock analyses of turtles in foraging areas or those caught as bycatch in fisheries.

In Australia, olive ridley nesting is scattered across many rookeries throughout the Northern Territory (Chatto \& Baker 2008), with an estimated few thousand females nesting annually (Pritchard \& Plotkin 1995, Whiting et al. 2007b). In 1999, the Australian Government upgraded the threatened status of olive ridley turtles from Vulnerable to Endangered, indicating recognition of the risk of extinction within Australian waters. While the number of nesting females in Australia is relatively small compared to populations in other regions (e.g. India, Mexico and Costa Rica) (Hamann et al. 2003, Plotkin 2007), it appears to be the largest in SE Asia and the eastern Indian Ocean. Low density nesting is found along $350 \mathrm{~km}$ of the western coast of Cape York Peninsula, Queensland, between Rutland Plains $\left(15^{\circ} 43^{\prime} \mathrm{S}\right)$ and Cape York $\left(10^{\circ} 42^{\prime} \mathrm{S}\right)$, with an estimated tens of turtles per season at any one beach (Limpus 2008). There are only 3 records of olive ridley clutches laid in Western Australia (Prince et al. 2010). Throughout their distribution in Australia, olive ridley eggs are subject to high levels of predation by feral pigs, dogs, monitor lizards Varanus spp. and Indigenous harvest at several locations (Whiting et al. 2007b, Chatto \& Baker 2008, Limpus 2008), and all other life stages face additional threats once turtles enter the marine habitat. This is of particular concern for the western Cape York rookery, as there are low numbers of nesting turtles and a history of high levels of egg and hatchling predation (C. J. Limpus unpubl. data).

One of the significant threats to foraging or migrating olive ridley turtles in northern Australia is the occurrence of large quantities of lost and discarded fishing gear, known as 'ghost nets' (Kiessling 2003, Gunn et al. 2010, Wilcox et al. 2013). These nets are lost or discarded by open-ocean fisheries or from coastal waters near towns in the Arafura and Timor Seas and SE Asia and, as they drift, they entangle and kill several marine species including olive ridley turtles (White 2006, Drysdale et al. 2009, Gunn et al. 2010). Some of these nets can be several kilometres long and form a ball floating at the surface that provides a structure for attachment by a variety of marine organisms and thus attracts many grazers and browsers including juvenile and adult turtles. While unquantified, the number of turtles killed in ghost nets within the Gulf of Carpentaria (GoC) appears to be hundreds and possibly thousands annually (Limpus 2008). Given the estimate of only a few thousand nesting olive ridley females annually, the Australian rookeries are unlikely to withstand an annual mortality of many hundreds of turtles over the long term (Limpus 2008).

In this study we used mtDNA control region sequences to examine the genetic relationships among 3 olive ridley rookeries in Australia and compared those rookeries to global populations. Secondly, we examined the composition of mtDNA haplotypes from turtles caught in ghost nets to investigate their population origin and to help set conservation priorities for this species.

\section{MATERIALS AND METHODS}

\section{Sample collection}

Tissue samples were collected from 102 nesting olive ridley females at 3 Australian rookeries: the Tiwi Islands $(\mathrm{n}=64)$ and the McCluer Group islands $(n=11)$ in the Northern Territory and Flinders Beach $(n=27)$ on the western Cape York Peninsula (CYP) in Queensland (Fig. 1). Samples were taken from turtles nesting at 4 islands in the McCluer Group, from Cape Van Diemen, Melville Island, in the Tiwi Island Group and along the $24 \mathrm{~km}$ Flinders Beach, at Mapoon on the CYP (see Table 1). Samples were preserved in absolute alcohol or in $20 \%$ dimethyl sulfoxide (DMSO) in a saturated $\mathrm{NaCl}$ solution. In addition, to investigate the origins of olive ridley turtles caught in ghost nets, available samples from turtles recovered from ghost nets were collected along the western edge of the GoC by the Dhimurru rangers $(n=21)$ and by the Mapoon Indigenous Land Council along the eastern GoC $(n=23)$ (see Table 1$)$. The size of measured turtles from the ghost nets ranged from 30 to $78 \mathrm{~cm}$ (curved carapace length) and the turtles were classified as either alive, dead or decomposed. Unpublished sequences from rookeries in Indonesia were kindly made available for comparison with unknown ghost net haplotypes and for use in the phylogenetic analysis (I. B. W. Adnyana unpubl. data).

\section{Characterisation of mtDNA haplotypes}

DNA was extracted from tissue samples using a salting-out procedure. First, tissue was digested by Proteinase $\mathrm{K}\left(0.55 \mathrm{mg} \mathrm{ml}^{-1}\right)$ at $55^{\circ} \mathrm{C}$ overnight in 


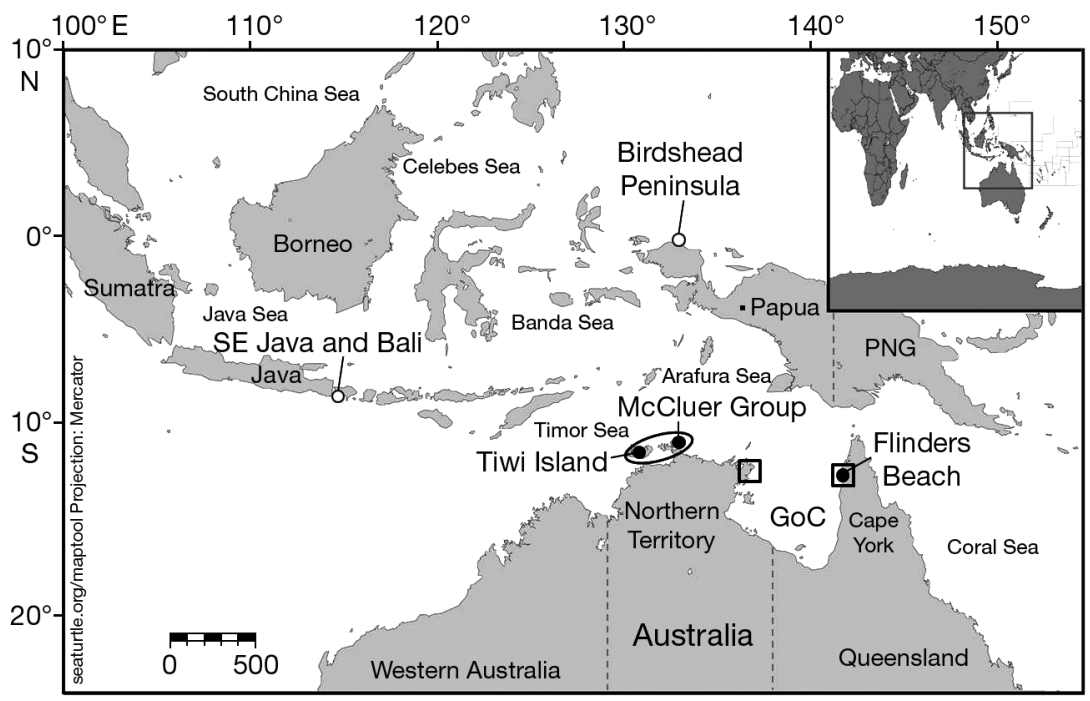

Fig. 1. (๑) The 3 olive ridley rookeries in Australia sampled for this study, (O) the origins of the additional sequences used from nesting sites in SE Java/Bali and the Birdshead Peninsula, Papua in Indonesia, and ( $\square$ ) sites for ghost net samples in the eastern and western Gulf of Carpentaria (GoC). Ellipse encloses Tiwi Island/McCluer Group management unit

lysis buffer $\left(300 \mu l_{i} 40 \mathrm{mM}\right.$ Tris/HCl, $20 \mathrm{mM}$ EDTA, $100 \mathrm{mM} \mathrm{NaCl}, \mathrm{pH} 7.2$ ) and $15 \mu \mathrm{l}$ of $10 \%$ sodium dodecyl sulphate (SDS). This was followed by precipitation of the fractionate with ammonium acetate $\left(150 \mu \mathrm{l}_{\text {; }}\right.$ $7.5 \mathrm{M})$ and ethanol precipitation $(100 \%, 2 \times$ volume $)$ of the DNA from the supernatant. DNA pellets were

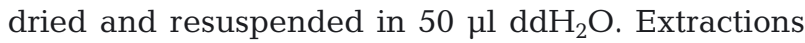
were checked for DNA quality and quantity by running $4 \mu \mathrm{l}$ through a $1.2 \%$ agarose gel and visualising with SYBR ${ }^{\circledR}$ Safe (Invitrogen) stain under UV light. Samples were amplified via polymerase chain reactions (PCR) using the primers LTEi9 (5'-AGC GAA TAA TCA AAA GAG AAG G-3') and H950 (5'-GTC TCG GAT TTA GGG GTT TA-3') (Abreu-Grobois et al. 2006). These primers amplify an $\sim 880 \mathrm{bp}$ fragment of the mtDNA control region. For the genetic analysis, sequences were truncated to $\sim 780 \mathrm{bp}$ to ensure good quality sequence. This region overlaps the 470 bp segment used by Bowen et al. (1997) in a previous study that included 7 of the same samples from the McCluer Group. PCRs were set up in $25 \mu \mathrm{l}$ reactions containing $1 \times$ reaction buffer, $0.25 \mathrm{mM}$ of each deoxynucleoside triphosphate, $1.5 \mathrm{mM} \mathrm{MgCl}_{2}, 10 \mu \mathrm{M}$ of each primer, $1.25 \mathrm{U}$ of Taq polymerase and $\sim 40 \mathrm{ng}$ of template DNA. The PCRs were carried out on an Eppendorf Mastercycler ${ }^{\circledR}$ ep thermocycler using an initial denaturing step at $94^{\circ} \mathrm{C}$ for $5 \mathrm{~min}$, followed by 35 cycles of $45 \mathrm{~s}$ at $94^{\circ} \mathrm{C}$ (denaturing), $45 \mathrm{~s}$ at $52^{\circ} \mathrm{C}$ (annealing) and $45 \mathrm{~s}$ at $72^{\circ} \mathrm{C}$ (extension), and a final extension step of $5 \mathrm{~min}$ at $72^{\circ} \mathrm{C}$. PCR products were analysed for quality and quantity on agarose gels (as above), and all successfully amplified samples were purified prior to sequencing using a polyethylene glycol (PEG) procedure described by T. Glenn (www.mcdb.lsa. umich.edu/labs/olsen/files/PCR.pdf).

Sequencing of the forward and reverse reactions was carried out by Macrogen (Korea). Sequences were aligned using Clustal W (Thompson et al. 1994) as implemented within the software Geneious (V5.6.5) (Drummond et al. 2011). Haplotypes were matched against published haplotypes by doing a BLAST search on GenBank (www.ncbi.nlm.nih.gov/genbank/) and against available unpublished sequences from Australasia. All sequences were identified by the original name from published shorter sequences and/or given a new coding identification for Indo-Pacific olive ridley turtles using the prefix Lo (e.g. Lo1, Lo2, etc.) and submitted to GenBank.

\section{Molecular analysis}

Genetic diversity was calculated as haplotype (h) and nucleotide $(\pi ;$ Nei 1987$)$ diversities using the software Arlequin (v. 3.5) (Excoffier \& Lischer 2010). Haplotype diversity takes into account the number of haplotypes in a population and their frequency within that population. Nucleotide diversity additionally considers the mean number of nucleotide differences (mutations) among all pairs of haplotypes in the population. Higher levels of nucleotide diversity indicate higher levels of haplotype divergence within a population. Estimates for both measures of diversity vary between 0 and 1 . The genetic distance among mtDNA haplotypes was calculated as a corrected percent sequence divergence among haplotypes in the program MEGA (version 5.03) (Tamura et al. 2007). The program Modeltest 3.0 (Posada \& Crandall 1998) was used to find the best model for nucleotide substitution, and this identified the model HKY85 + G $(\alpha=0.1256)$ (Hasegawa et al. 1985) as appropriate for olive ridleys. The HKY85 + G model was then used to correct for multiple substitutions per site and different substitution rates between transitions and transversions. Genetic differentiation among sampling locations was tested using 2 different measures of popula- 
tion differentiation; a conventional $F_{\mathrm{ST}}$ test based only on haplotype frequencies (Slatkin 1995), and the sequence-based $\phi_{\mathrm{ST}}$ test. Both the $F_{\mathrm{ST}}$ and $\phi_{\mathrm{ST}}$ tests were performed using Arlequin (v. 3.5). Testing for differences in haplotype frequencies from ghost nets between the western and the eastern GoC was done using the program CHIRXC (Zaykin \& Pudovkin 1993). This program applies a randomised chi-square test to detect significant shifts in haplotype frequencies between the 2 sample locations.

A rarefaction curve was created using the rarefaction calculator (www.biology.ualberta.ca/jbrzusto/ rarefact.php) to assess haplotype richness at the rookeries relative to sampling effort. This curve is a plot of the number of haplotypes as a function of the number of samples.

A network of haplotype relationships was constructed based on statistical parsimony using the software TCS 1.13 (Templeton et al. 1992, Clement et al. 2000). Finally, the phylogenetic relationships among haplotypes was calculated based on $470 \mathrm{bp}$ of shared sequences from this study and from olive ridley turtles in Surinam, Brazil, Guinea Bissau, Pacific Costa Rica, Malaysia, Sri Lanka (Bowen et al. 1997), India (Shanker et al. 2004) and 2 regions in Indonesia (Birdshead Peninsula, West Papua and SE Java/Bali) (I. B. W. Adnyana unpubl. data). Four sequences from Lepidochelys kempii were used as an out-group in the analysis (Bowen et al. 1997). A maximum likelihood tree was built using PAUP 4.0 (Swofford 2002). Node support was assessed with nonparametric bootstrap analysis (1000 replicates).

\section{RESULTS}

Overall we identified 24 haplotypes across the $780 \mathrm{bp}$ fragment. These haplotypes were characterised by 17 transitions, 2 transversions and 2 indels. All haplotypes were new and submitted to GenBank (accession numbers JN391445 to JN391465, KC 207828 to KC207830).

\section{Rookery diversity}

Sequencing of the mtDNA from 102 nesting turtles revealed eight $780 \mathrm{bp}$ haplotypes (Table 1). In 5 of these haplotypes, the $470 \mathrm{bp}$ segment corresponded to 4 previously identified shorter haplotypes (Haplotypes M, G, H, J) presented by Bowen et al. (1997) and Shanker et al. (2004). Of these 4 shorter haplotypes, 2 were previously identified from the McCluer

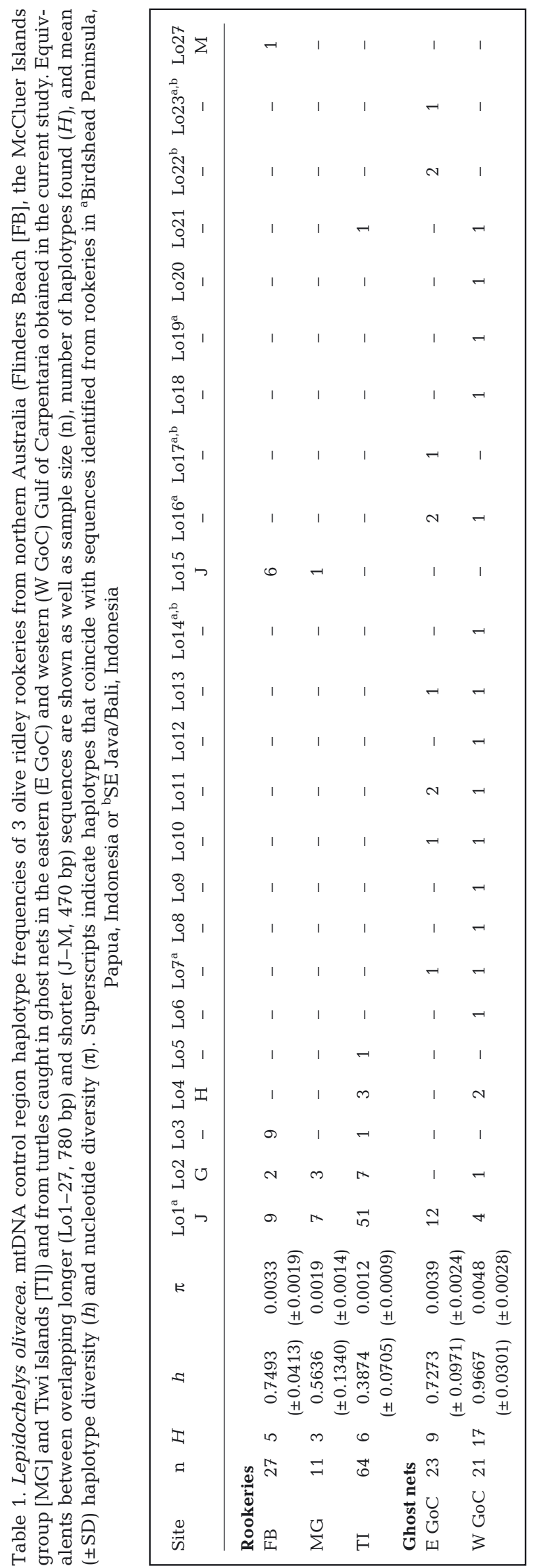


Group (G and J), 2 from Sri Lanka (J and H), 1 from Malaysia (J), 1 from India (J) and 1 from Costa Rica (M) (Bowen et al. 1997, Shanker et al. 2004). Of the longer haplotypes we found, Lo1 was the most common haplotype (66\%) and it was found at all 3 rookeries sampled. Lo2 was also found at all 3 rookeries but at low frequency at Flinders Beach $(7 \%)$ and the Tiwi Islands $(11 \%)$, and a higher frequency at the McCluer Group (27\%). Lo3 was found at a low frequency $(<2 \%)$ at the Tiwi Islands rookery and at a higher frequency (33\%) at the Flinders Beach rookery. Lo4 and Lo5 were only found at the Tiwi Islands rookery and only at low frequencies $(<4 \%$ and $<2 \%$, respectively). Lo15 was found at the McCluer Group (10\%, 1 individual) and Flinders Beach (22\%) rookeries. One haplotype, Lo27, was only found at Flinders Beach at a low frequency (4\%).

Genetic diversity in the sampled rookeries was low to moderate. Haplotype diversity varied between 0.39 and 0.75, and estimates of nucleotide diversity were low and ranged from 0.0012 to 0.0033 (Table 1). The low level of nucleotide diversity was reflected in the shallow divergence among the 7 haplotypes, with sequence divergence ranging from 0.1 to $0.8 \%$. Construction of a haplotype network showed that these rookery haplotypes varied by 1 to 8 mutations (Fig. 2).

\section{Population differentiation}

The neighbouring Tiwi Islands and McCluer Group rookeries, which are separated by just $200 \mathrm{~km}$, were not genetically differentiated using either the conventional $F_{\mathrm{ST}}\left(F_{\mathrm{ST}}=0.0056, \mathrm{p}=0.307\right)$ or the sequence-

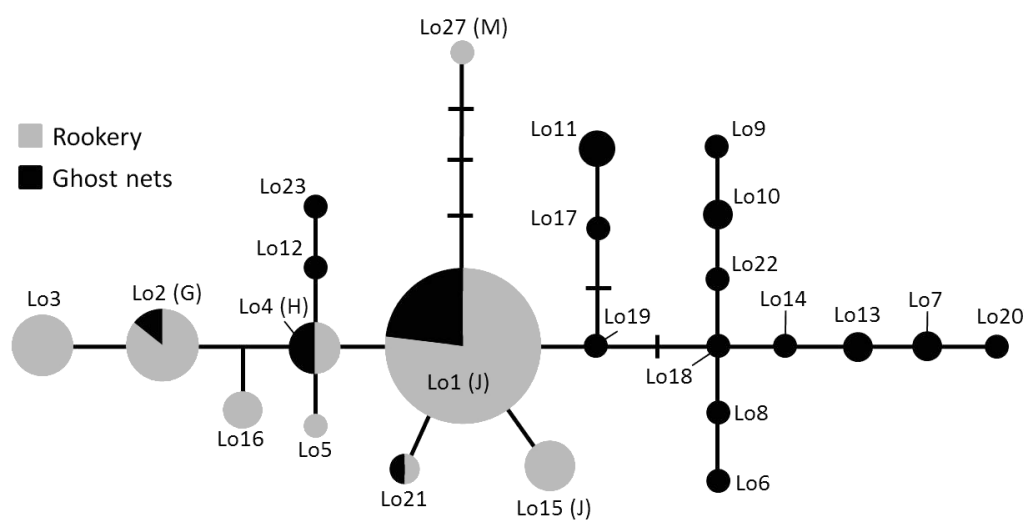

Fig. 2. Lepidochelys olivacea. Haplotype network based on maximum parsimony of $780 \mathrm{bp}$ of the mtDNA control region. Vertical and horizontal bars represent 1 extra mutational step connecting 2 haplotypes. Pie charts represent the distribution of the haplotypes at either 1 of the 3 Australian rookeries (grey) or samples from ghost nets (black). The size of the circles represents the relative frequency of the haplotypes out of the total sample based $\phi_{\mathrm{ST}}\left(\phi_{\mathrm{ST}}=0.004, \mathrm{p}=0.303\right)$ distance estimates. In contrast the Flinders Beach and Tiwi Islands rookeries, which are $1200 \mathrm{~km}$ apart, were genetically differentiated under both methods of analysis $\left(F_{\mathrm{ST}}=\right.$ $0.244, \mathrm{p}<0.001$ and $\left.\phi_{\mathrm{ST}}=0.168, \mathrm{p}=0.0009\right)$. The Flinders Beach and McCluer Group rookeries, which are $1000 \mathrm{~km}$ apart, were significantly differentiated when using $F_{\mathrm{ST}}\left(F_{\mathrm{ST}}=0.109, \mathrm{p}=0.039\right)$ but not when using $\phi_{\mathrm{ST}}\left(\phi_{\mathrm{ST}}=0.017, \mathrm{p}=0.274\right)$. However, when combining the 2 neighbouring (and genetically indistinguishable) Tiwi and McCluer rookeries, they were highly differentiated from Flinders Beach under both methods of analysis $\left(F_{\mathrm{ST}}=0.236, \mathrm{p}<0.001\right.$ and $\phi_{\mathrm{ST}}=$ 0.157, p < 0.0007).

\section{Genetic composition of captures by ghost nets}

The genetic composition of turtles caught in ghost nets varied between the eastern GoC ( $\mathrm{n}=23$ ) and western GoC $(n=21)$. The genetic diversity in the eastern GoC ghost net samples was similar or slightly higher than that of the rookery samples for haplotype ( $h=0.73)$ and nucleotide $(\pi=0.0039)$ diversity, while the western GoC showed a much greater genetic diversity than the rookery samples for both haplotype $(h=0.97)$ and nucleotide $(\pi=0.0048)$ diversity) (Table 1). A total of 17 mtDNA haplotypes were identified among western GoC samples in comparison to the 9 haplotypes found in the eastern GoC samples (Table 1). The randomised chi-square test indicated low but significant variation in the haplotype frequencies of turtles sampled from the 2 regions $(\mathrm{p}=$ 0.035). The common rookery haplotype Lo1 was also the most common haplotype found in the eastern GoC (52\%) and the western GoC (19\%) ghost net samples. An additional 3 Australian rookery haplotypes were identified among the western GoC samples (Lo2, Lo4 and Lo21), but at low frequency. Eight haplotypes from the ghost net samples matched unpublished haplotypes recently identified at 2 rookeries in Indonesia (Table 1, Figs. 1 \& 3) (I. B. W. Adnyana unpubl. data), 7 of which were not found among the Australian rookeries. The remaining 9 haplotypes found across the 2 ghost net locations were each present at low frequency $(<7 \%)$, but together made up $32 \%$ of the total ghost net sample and are 'orphan' haplotypes that have not been found in any nesting 


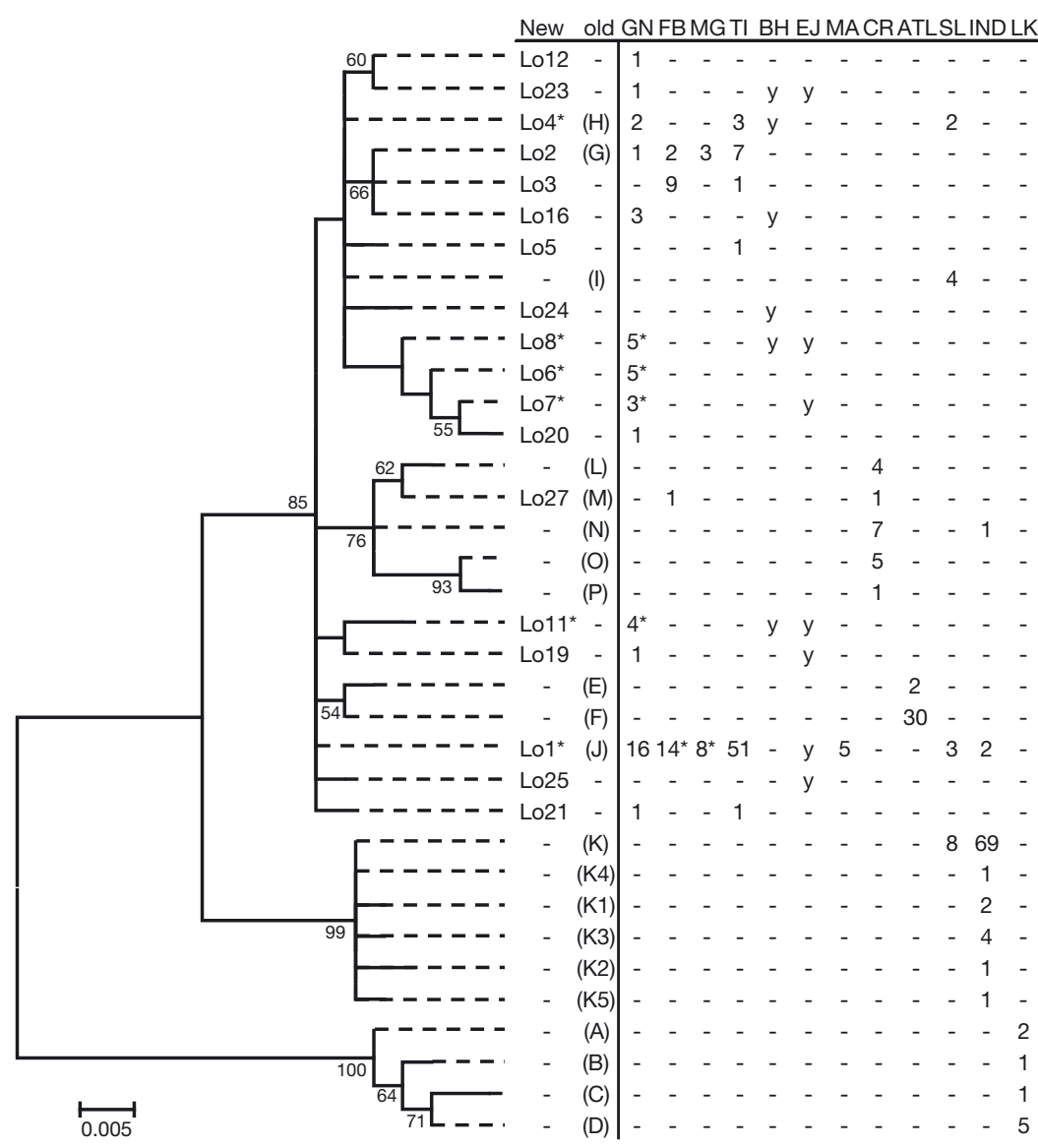

Fig. 3. Lepidochelys olivacea. Evolutionary relationships of haplotypes based on 470 bp mtDNA sequence. The evolutionary history was inferred using the maximum likelihood method. The percentage of replicate trees in which the associated taxa clustered together in the bootstrap test (1000 replicates) is shown next to the branches (only values above $50 \%$ are shown). Haplotypes and their frequencies are shown for samples collected in the ghost nets (GN), and at rookeries at Flinders Beach (FB), McCluer Group (MG) Islands, Tiwi Islands (TI) (this study), Birdshead Peninsula (BH) and East Java (EJ) (I. B. W. Adnyana pers. comm.), Malaysia (MA), Costa Rica (CR), Atlantic Ocean (ATL), Sri Lanka (SL) (Bowen et al. 1997) and India (IND) (Shanker et al. 2004). L. kempii (LK) was used as an outgroup (Bowen et al. 1997). y (for BH and EJ): haplotypes found in those rookeries but no frequency data is available. Haplotypes marked with an asterisk are different at the $780 \mathrm{bp}$ but identical at the $470 \mathrm{bp}$ used for the tree: Lo1 = Lo15, Lo7 = Lo9, Lo6 = Lo10 and Lo13, Lo8 = Lo14, Lo18 and Lo22, Lo4 = Lo26, and Lo11 = Lo17 (see Table 1)

in the population is represented within the sample, but the curve for Cape York is still increasing, although starting to level off. This suggests that increased sampling could reveal additional haplotypes at low frequency in Cape York. It is unlikely, however, that this would account for the large number of orphan haplotypes found in the ghost net samples.

\section{Phylogeography}

There were 2 ambiguous loops in the haplotype network (Fig. 2) that were resolved using Pfenninger \& Posada's (2002) criteria. Overall, the haplotype network reflected the low divergence among all nesting samples. The common Haplotype Lo1 $(\mathrm{J})$ is also found in Indonesia, India, Sri Lanka and Malaysia. This haplotype is central in the network and is likely an ancestral haplotype from which other haplotypes in the Indo-Pacific were derived, thus suggesting that this haplotype was central to the (re)colonisation of the Atlantic and Pacific Oceans. Most of the haplotypes found in samples from ghost nets form their own cluster of closely related haplotypes that include the orphan haplotypes that have not been identified at any rookery to date. The phylogenetic tree showed poor bootstrap support for most branches due to the low sequence divergence among olive ridley haplotypes (Fig. 3). There

population to date. These orphan haplotypes showed slightly more divergence (sequence divergence range from 0.1 to $1.0 \%$ ) than the Australian rookery samples (sequence divergence range from 0.1 to $0.8 \%$ ). The haplotype network indicated greater complexity among ghost net samples than that found within the rookery samples (Fig. 2). To consider whether the orphan haplotypes may be due to low sample size in our nesting samples we created a rarefaction curve (Fig. 4). The visibly asymptotic curve for the Northern Territory indicates that the most of the diversity were, however, some clear patterns in the tree. The K haplotypes found only in India and Sri Lanka had high support as a distinct and divergent clade relative to all other olive ridley haplotypes. There was some support ( $>60 \%$ bootstrap) for the grouping of eastern Pacific haplotypes (L, M, N, O, $\mathrm{P})$. It is worth noting that 1 turtle from Flinders Beach had Haplotype Lo27, which is identical to the eastern Pacific Haplotype $M$ for the $470 \mathrm{bp}$ fragment. A similar scenario was found in India, where an eastern Pacific haplotype (N) was found 


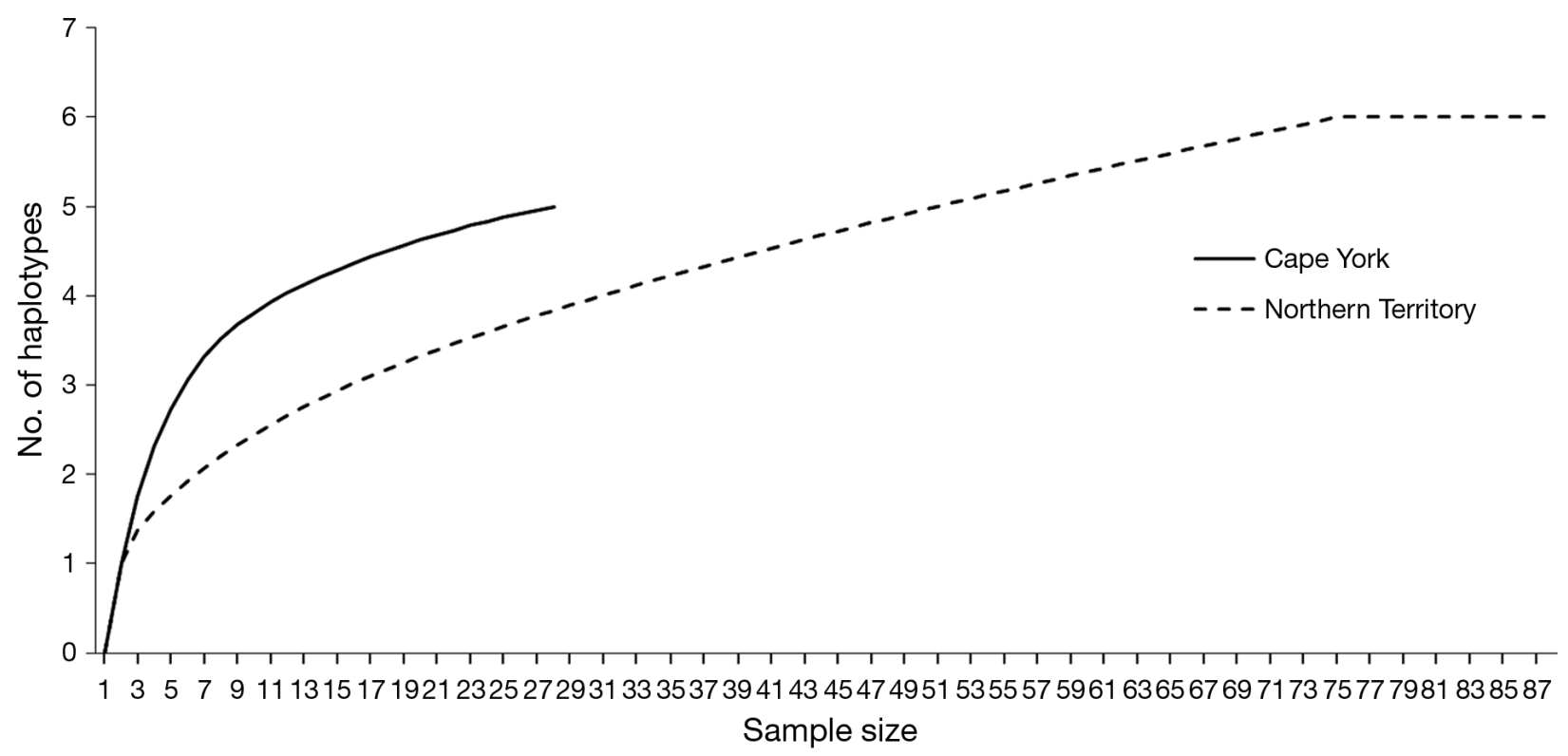

Fig. 4. Lepidochelys olivacea. Rarefaction curve of samples collected from the 2 genetic stocks (Cape York and the Northern Territory). The 2 curves plot the number of haplotypes as a function of the number of samples

at low frequency (Shanker et al. 2004). Future long sequencing of East Pacific olive ridleys with Haplotype $\mathrm{M}$ and $\mathrm{N}$ could help determine if they are identical for the longer fragment. There was little genetic distance between Atlantic and Pacific haplotypes, but some support (52\% bootstrap) grouping the Atlantic haplotypes ( $\mathrm{E}$ and $\mathrm{F}$ ). There was also low support (61\% bootstrap) for a clade containing a mix of haplotypes from throughout SE Asia (including Australia) and many of the 'orphan' haplotypes from the ghost net samples.

\section{DISCUSSION}

This study indicates that the critically small olive ridley population nesting along western Cape York is genetically isolated from the larger population in the Northern Territory that nests around the Tiwi Islands and the McCluer Group (Limpus 2008), and should thus be regarded as a separate MU. The genetic results are also consistent with the notion that insufficient numbers of turtles from the Northern Territory nest along western Cape York and that connectivity is so low that it is unlikely for the former to recolonise the area in the event of population extirpation. Additionally, it appears that entanglement of olive ridley turtles by ghost nets is impacting not only the Australian rookeries, but also more distant rookeries in the region.

\section{Genetic diversity and phylogeography}

Genetic diversity within Australian rookeries is moderate, with closely related haplotypes that appear to have diverged from 2 common haplotypes (Lo1 $[\mathrm{J}]$ and Lo4 $[\mathrm{H}]$ ), similar to observations of divergent haplotypes from Atlantic and eastern Pacific rookeries. All haplotypes observed in the rookery and ghost net samples come from the lineage of Indo-Pacific and Atlantic haplotypes that are separated from the previously observed K clade of India, which is thought to be the ancestral source for the contemporary distribution of olive ridley turtle populations (Bowen et al. 1997, Shanker et al. 2004). Haplotype J, which we have identified as 2 haplotypes, Lo1 and Lo15 (using 780 bp), has been observed at rookeries in India (Shanker et al. 2004), Sri Lanka, Malaysia (Bowen et al. 1997), Indonesia (I. B. W. Adnyana unpubl. data), the Tiwi Islands, the McCluer islands and western Cape York (Fig. 3), and in stranded turtles caught in ghost nets. The splitting of the common $\mathrm{J}$ haplotype when using longer sequences was helpful in characterising population boundaries of the Australian populations and will prove useful once additional samples are sequenced from throughout the region. Tests for genetic divergence between rookeries in Australia and Sri Lanka verify the separation of these populations (Sri Lanka and Northern Territory $F_{\mathrm{ST}}=0.508$; Sri Lanka and western Cape York $F_{\mathrm{ST}}=0.281$ ). 
Unfortunately, sample sizes from Malaysia were too small for comparisons, but all 5 samples had the $\mathrm{J}$ haplotype (Bowen et al. 1997). Comparisons with green turtles, which share the same nesting regions, suggest that populations in neighbouring countries will be genetically distinct (Dethmers et al. 2006, Jensen 2010), but the geographic spread of olive ridley haplotypes in the Atlantic and eastern Pacific (Bowen et al. 1997, Shanker et al. 2004, LópezCastro \& Rocha-Olivares 2005) suggests that the divergent haplotypes in Australia will be observed at other rookeries within the region. Previous analyses suggest that there has been a range expansion in olive ridley turtles between Sri Lanka and Australia, and long-distance colonisation, likely from west to east across the Indian Ocean (Shanker et al. 2004), which is consistent with the observed new rookery haplotypes that have little genetic divergence. Similar to the findings of Shanker et al. (2004) in India, the presence of an eastern Pacific haplotype in Australia supports the hypothesis that infrequent, long-distance dispersal of this species occurred at some time in the past.

Estimates of genetic divergence and diversity have provided insights into marine turtle colonisation histories (Shanker et al. 2004, López-Castro \& Rocha-Olivares 2005), including within the study area (Dethmers et al. 2006). The Arafura Sea-GoC areas of the Australian-New Guinea continental shelf were terrestrial habitat during the Pleistocene lower sea levels. Colonisation by nesting marine turtles was only possible following sea level rises towards the end of the last ice age, with flooding of the western Arafura Sea into the GoC sometime after 12000 yr BP (Yokoyama et al. 2001). Gillieson (2005) summarised sand dune geomorphology for the coastal areas of western CYP near Mapoon, concluding that postglacial sea level rise in northern Australia ceased by about 5500 yr BP and was associated with widespread coastal dune formation and periodic reworking of Pleistocene sand masses. In green turtles, colonisation of beaches in the western and southern GoC from the west, and subsequent genetic divergence, is indicated by larger mtDNA genetic divergence found between the populations in the GoC and northern Great Barrier Reef $\left(F_{\mathrm{ST}}=0.65\right)$ in comparison to that between the GoC and Northwest Shelf (Western Australia) $\left(F_{\mathrm{ST}}=0.26\right)$ populations (FitzSimmons et al. 1997). Additionally, the prevalence of haplotypes that are shared between the GoC population and populations from Western Australia and SE Asia, rather than from populations in the Pacific, further suggests colonisa- tion from the north or west, followed by genetic isolation (Dethmers et al. 2006). A similar scenario may have occurred during olive ridley colonisation of the GoC, given the sharing of the 3 most common haplotypes, in addition to possibly having unique haplotypes in each population. It appears that genetic divergence has occurred between olive ridley populations in the Northern Territory and western Cape York $\left(F_{\mathrm{ST}}=0.24\right)$ since the colonisation of this area from the western Indian Ocean (Shanker et al. 2004). In contrast, a lower level of genetic divergence was observed among flatback rookeries in the Northern Territory and GoC (mean $F_{\mathrm{ST}}=0.05$; Pittard 2010), and no divergence was observed between hawksbill turtle rookeries in the Northern Territory and northern Queensland (Broderick et al. 1994), suggesting either a delayed colonisation by these species or ongoing gene flow.

\section{Ghost nets and conservation issues}

The nesting distribution and densities of olive ridley turtles throughout SE Asia, the eastern Indian Ocean and the western Pacific Ocean have been poorly documented, and even less is known of foraging populations in the region. The high number of orphan haplotypes found in ghost net samples highlights the need for a more extensive sampling of olive ridley rookeries in SE Asia and the western Pacific. Outside of Australia, adult and immature olive ridley turtles are both known to make long-distance migrations to forage in distant pelagic areas in the open ocean (Polovina et al. 2004, Morreale et al. 2007, Plotkin 2007). In contrast, satellite telemetry studies of adult of olive ridley turtles breeding in the Northern Territory indicate that they disperse to a range of different foraging areas but appear to remain over the northern Australian continental shelf where they forage on benthic communities (Conway 1994, McMahon et al. 2007, Whiting et al. 2007a, Conway \& Guinea 2009). Flipper tag recoveries and genetic studies of green turtles in foraging grounds around northern Australia (Limpus 2007, Dethmers et al. 2010, Jensen 2010) have indicated that these foraging populations are composed of turtles from various rookeries throughout the region, including Indonesia and Malaysia (Limpus 2007, Dethmers et al. 2010). Foraging olive ridley turtles in the region are also likely to include at least a significant proportion of adult and immature turtles from rookeries outside Australia (particularly Indonesia and Papua New Guinea). However, it is becoming less likely that for- 
aging turtles in the Arafura Sea have come from Malaysian rookeries as they had severely declined to a few turtles by the mid-1990s (Chan 2006, AbreuGrobois and Plotkin 2008) and the estimated age to maturity in this species is only 10 to $18 \mathrm{yr}$ (Zug et al. 2006).

Every year, thousands of abandoned or lost fishing nets (ghost nets) are found along the beaches of the GoC and the northern coast of the Northern Territory. While a few of these are from the Australian prawn fishery, most (>90\%) are thought to be of foreign origin, probably from fisheries operating in Indonesian waters (Kiessling 2003, White 2006). It is unknown where these nets are discarded, but many enter the GoC where they entangle and kill many fish, sharks, and turtles while drifting (White 2006, Limpus 2008, Gunn et al. 2010). The majority of these nets are found on the eastern side of the GoC from Cape York to south of Weipa during the wet season when the northwest monsoon winds blow, and on the western side of the $\mathrm{GoC}$ from Cape Arnhem to Groote Eylandt during the dry season when the southeast trade winds blow (Gunn et al. 2010). Our haplotype results from stranded turtles caught in ghost nets revealed that $45 \%$ of the haplotypes ( $32 \%$ of all 'ghost net' samples) have not been observed at any rookery and their nesting origin is therefore not traceable at present. The remaining 11 haplotypes matched those found in the Australian rookeries or in 2 rookeries in Indonesia, but low sample numbers prevent any meaningful mixed stock analysis. These findings do however suggest that Australian rookeries in the Northern Territory as well as within the GoC are losing turtles to the ghost nets. This conclusion is corroborated by satellite tracking data of a turtle tagged while nesting at the Tiwi Islands that subsequently foraged along the western GoC (Whiting et al. 2007a). While our sample sizes are small and any conclusions have to be interpreted with caution, the difference in haplotype composition between the eastern and western GoC ghost net samples indicate that nets stranding along the western $\mathrm{GoC}$ are catching a genetically more diverse group of turtles, which presumably have more diverse origins than those caught in nets found in the eastern GoC. Overall, the presence of 16 orphan haplotypes in the ghost net samples indicates that these turtles likely originate from several rookeries. Given the placement of the unknown haplotypes in the neighbour-joining tree (Fig. 3), it would not be surprising to find that ghost nets are impacting rookeries that span a large geographical area. The neighbour-joining tree places many of the orphan haplotypes in their own clade, suggesting that there remain significant unsampled rookeries in the Indo-Pacific.

At this point, it remains unclear whether the diverse mixture of haplotypes found in the ghost nets result from entanglement within the $\mathrm{GoC}$ of a diverse mixed stock of turtles foraging within the GoC or from turtles foraging at more distant locations that were captured by ghost nets that subsequently drifted into the GoC. The presence of several (8 of 16 recorded) turtles that were still alive in the ghost nets in the western GoC, suggests that these turtles could have drifted in from no further away than the adjacent Arafura Sea. In contrast, all 8 ghost net entangled turtles from the western GOC that were classed as either 'dead' or 'decomposed' either had orphan haplotypes, or those found only in Indonesia, suggesting support for longer transport distances. Future work on ghost nets should attempt to document the relative amount of time a ghost net has drifted based on epibionts, as well as collecting data on the size and condition of entangled turtles.

This study adds to the growing body of evidence that concerted conservation action is needed to manage the Australian olive ridley populations, particularly those from the western Cape York beaches, to guarantee the survival of this threatened population into the future. Decades of high depredation of eggs by feral pigs, feral dogs and varanids, previous incidental bycatch in prawn trawl nets (Poiner \& Harris 1996) and other fisheries, Indigenous harvest, and unknown numbers of turtles killed in ghost nets have put olive ridley populations in Australia under risk of extinction (Limpus 2008). To better understand the status of the Australian populations, it is important to increase the genetic sampling throughout their range. Sporadic and low-density nesting occurs within the western $\mathrm{GoC}$ at the Sir Edward Pellew Islands and Groote Eylandt in the Northern Territory. Sampling of these beaches will help determine whether these turtles belong to the Arnhem Land or to the western Cape York stock. More broadly, additional sampling of other olive ridley rookeries in the region, including in southern Papua New Guinea, are needed to determine population boundaries and allow a better evaluation of the origin of turtles caught in ghost nets. Field studies aimed at increasing nesting success are being conducted in western Cape York in conjunction with Indigenous ranger groups, and new studies on ghost nets have been initiated that will aid in our understanding and the conservation of the olive ridleys in Australia. 
Acknowledgements. We sincerely thank volunteers of the Queensland Turtle Conservation Project of the Department of Environment and Heritage Protection (QDEHP) and L. Booth and other Mapoon Indigenous Land and Sea Rangers and the Marine Ranger Program of the Mapoon Aboriginal Shire Council for assisting in collection of the samples of nesting turtles and turtles in ghost nets on the Mapoon beaches. The sampling would not have occurred without the collaboration between the Mapoon Aboriginal Shire Council, the traditional owners of Mapoon lands, the local Indigenous rangers and the Queensland Turtle Conservation Project. The sampling at the Tiwi Islands would not have occurred if not for the collaborative relationship with Traditional Owners C. Kalippa and Murphy, D. Tippakalippa, J. Long and K. Hadden of the Tiwi Land Council Marine Ranger Program and A. Lauder of NT Coastcare. We thank the Dhimurru Aboriginal Corporation, the many Indigenous rangers and the scientists and volunteers who have contributed to the Dhimurru Miyapunu (Marine Turtle) Project for providing samples from turtles entrapped in ghost nets in the Western Gulf of Carpentaria, Northern Territory, Australia. Many thanks to S. Pittard and N. Aitken for providing laboratory assistance. Earlier drafts of the manuscript benefited from comments by C. Wabnitz, D. Waayers, J. van de Merwe, B. Shamblin and C. Allen. Funding was provided on the Tiwi Islands by the Australian Government Natural Heritage Trust, Caring for our Country programs and the Queensland Department of Environment and Heritage Protection. The genetic sampling in Queensland was conducted as part of the Queensland Turtle Conservation Project of the Department of Environment and Heritage Protection. The sampling in the Northern Territory was collected under wildlife permits through Northern Territory Parks and Wildlife and Animal Ethics from Charles Darwin University (A4005).

\section{LITERATURE CITED}

Abreu-Grobois A, Plotkin P (IUCN SSC Marine Turtle Specialist Group) (2008) Lepidochelys olivacea. In: IUCN Red List of Threatened Species, Version 2012.2. IUCN, Gland

Abreu-Grobois FA, Horrocks JA, Formia A, Dutton PH and others (2006) New mtDNA D-loop primers which work for a variety of marine turtle species may increase the resolution of mixed stock analysis. In: Frick M, Panagopoulou A, Rees AF, Williams K (eds) Proc 26th Annu Symp Sea Turtle Biology and Conservation, Crete, 3-8 April 2006. International Sea Turtle Society, Athens, p 179

Bass AL (1999) Genetic analysis to elucidate the natural history and behavior of hawksbill turtles (Eretmochelys imbricata) in the wider Caribbean: a review and reanalysis. Chelonian Conserv Biol 3:195-199

Bass AL, Epperly SP, Braun-McNeill J (2006) Green turtle (Chelonia mydas) foraging and nesting aggregations in the Caribbean and Atlantic: impact of currents and behavior on dispersal. J Hered 97:346-354

Bernardo J, Plotkin PT (2007) An evolutionary perspective on the arribada phenomenon and reproductive behavioral polymorphism of olive ridley sea turtles (Lepidochelys olivacea). In: Plotkin P (ed) Biology and conservation of ridley sea turtles. Johns Hopkins University Press, Baltimore, MD, p 59-88
Bowen BW (1995) Tracking marine turtles with genetic markers: voyages of the ancient mariners. BioScience 45 : 528-534

Bowen BW, Meylan AB, Ross JP, Limpus CJ, Balazs GH, Avise JC (1992) Global population structure and natural history of the green turtle (Chelonia mydas) in terms of matriarchal phylogeny. Evolution 46:865-881

Bowen BW, Bass AL, Garcia-Rodriguez A, Diez CE and others (1996) Origin of hawksbill turtles in a Caribbean feeding area as indicated by genetic markers. Ecol Appl 6:566-572

- Bowen BW, Clark AM, Abreu-Grobois FA, Chaves A, Reichart HA, Ferl RJ (1997) Global phylogeography of the ridley sea turtles (Lepidochelys spp.) as inferred from mitochondrial DNA sequences. Genetica 101:179-189

Broderick D, Moritz C, Miller JD, Guinea M, Prince RIT, Limpus CJ (1994) Genetic studies of the hawksbill turtle Eretmochelys imbricata: evidence for multiple stocks in Australian waters. Pac Conserv Biol 1:123-131

> Browne D, Horrocks JA, Abreu-Grobois FA (2010) Population subdivision in hawksbill turtles nesting on Barbados, West Indies, determined from mitochondrial DNA control region sequences. Conserv Genet 11:1541-1546

Chan EH (2001) Status of marine turtle conservation and research in southeast Asia. In: Schäuble C, Hien BTT (eds) Proc Vietnam's First National Workshop on Marine Turtle Conservation, IUCN-Vietnam and Ministry of Fisheries, Hanoi

Chan EH (2006) Marine turtles in Malaysia: On the verge of exstinction? Aquat Ecosys Health Manag 9:175-184

Chassin-Noria O, Abreu-Grobois FA, Dutton PH, Oyama K (2004) Conservation genetics of the East Pacific green turtle (Chelonia mydas) in Michoacan, Mexico. Genetica 121:195-206

Chatto R, Baker B (2008) The distribution and status of marine turtle nesting in the Northern Territory. Parks and Wildlife Service, Department of Natural Resources, Environment, The Arts and Sport, Northern Territory Government, Darwin

> Clement M, Posada D, Crandall KA (2000) TCS: a computer program to estimate gene genealogies. Mol Ecol 9: 1657-1659

Conway SP (1994) Diets and feeding biology of adult olive ridley (Lepidochelys olivacea) and loggerhead (Caretta caretta) sea turtles in Fog Bay (Northern Territory). Postgraduate Diploma of Science thesis, Northern Territory University, Darwin

Conway SP, Guinea ML (2009) Diet and feeding biology of adult olive ridley (Lepidochelys olivacea) and loggerhead (Caretta caretta) sea turtles in Fog Bay, Northern Territory. In: Belskis L, Frick M, Panagopoulou A, Rees A, Williams K (eds) Proc 29th Annu Symp Sea Turtle Biology and Conservation, Brisbane, 17-19 Feb 2009. NOAA Tech Memo NOAA NMFS-SEFSC-630, p 4

> da Silva ACCD, de Castilhos JC, Lopez GG, Barata PCR (2007) Nesting biology and conservation of the olive ridley sea turtle (Lepidochelys olivacea) in Brazil, 1991/ 1992 to 2002/2003. J Mar Biol Assoc UK 87:1047-1056

da Silva ACCD, dos Santos EAP, Oliveira FLdC, Weber MI, Batista JAF, Serafini TZ, de Castilhos JC (2011) Satellitetracking reveals multiple foraging strategies and threats for olive ridley turtles in Brazil. Mar Ecol Prog Ser 443: 237-247

Dethmers KEM, Broderick D, Moritz C, FitzSimmons NN and others (2006) The genetic structure of Australasian 
green turtles (Chelonia mydas): exploring the geographical scale of genetic exchange. Mol Ecol 15:3931-3946

> Dethmers KEM, Jensen MP, FitzSimmons NN, Broderick D, Limpus CJ, Moritz C (2010) Migration of green turtles (Chelonia mydas) from Australasian feeding grounds inferred from genetic analyses. Mar Freshw Res 61: 1376-1387

Drummond AJ, Ashton B, Buxton S, Cheung $M$ and others (2011) Geneious v5.4. Available from www.geneious.com

Drysdale V, White P, Wise P, Roeger S (2009) Research on the impact of marine debris on marine turtle survival and behaviour: north east Arnhem Land, Northern Territory, Dhimurru Turtle Entanglement Report and Dhimurru Turtle Tracking Report. Dhimurru Aboriginal Corportaion, Nhulunbuy. Available at www.environment.gov. au/biodiversity/threatened/publications/pubs/marinedebris-dhimurru.pdf

> Dutton PH, Bowen BW, Owens DW, Barragan AR, Davis SK (1999) Global phylogeography of the leatherback turtle (Dermochelys coriacea). J Zool 248:397-409

> Dutton P, Roden S, Stewart KR, LaCasella E and others (2013) Population stock structure of leatherback turtles (Dermochelys coriacea) in the Atlantic revealed using mtDNA and microsatellite markers. Conserv Genet 14: 625-636

Encalada SE, Lahanas PN, Bjorndal KA, Bolker B, Miyamoto MM, Bowen BW (1996) Phylogeography and population structure of the Atlantic and Mediterranean green turtle Chelonia mydas: a mitochondrial DNA control region sequence assessment. Mol Ecol 5:473-483

> Excoffier L, Lischer HEL (2010) Arlequin suite ver 3.5: a new series of programs to perform population genetics analyses under Linux and Windows. Mol Ecol Resour 10: 564-567

FitzSimmons NN (1998) Single paternity of clutches and sperm storage in the promiscuous green turtle (Chelonia mydas). Mol Ecol 7:575-584

FitzSimmons NN, Moritz C, Limpus CJ, Pope L, Prince RIT (1997) Geographic structure of the mitochondrial and nuclear gene polymorphisms in Australian green turtle populations and male-biased gene flow. Genetics 147: 1843-1854

Gillieson D (2005) Coastal geomorphology and historic change in the Pennefather River area, Cape York. Geography Monograph Series 10 Royal Geographical Society of Queensland, Brisbane, p 201-213

Guinea ML, Chatto R (1992) Sea turtles killed in Australian shark fin fishery. Mar Turtle Newsl 57:5-6

Gunn R, Hardesty BD, Butler J (2010) Tackling 'ghost nets': local solutions to a global issue in northern Australia. Ecol Manage Restor 11:88-98

Hamann M, Limpus CJ, Owens DW (2003) Reproductive cycles of males and females. In: Lutz PL, Musick JA, Wyneken J (eds) The biology of sea turtles, Vol 2. CRC Press, Boca Raton, FL, p 135-161

> Hamann M, Cuong CT, Hong ND, Thuoc P, Thuhien BT (2006) Distribution and abundance of marine turtles in the Socialist Republic of Viet Nam. Biodivers Conserv 15: 3703-3720

> Hasegawa M, Kishino H, Yano T (1985) Dating of the human-ape splitting by a molecular clock of mitochondrial DNA. J Mol Evol 22:160-174

> Ireland JS, Broderick AC, Glen F, Godley BJ, Hays GC, Lee PLM, Skibinski DOF (2003) Multiple paternity assessed using microsatellite markers, in green turtles Chelonia mydas (Linnaeus, 1758) of Ascension Island, South Atlantic. J Exp Mar Biol Ecol 291:149-160

Jensen MP (2010) Assessing the composition of green turtle (Chelonia mydas) foraging grounds in Australasia using mixed stock analyses. PhD thesis, University of Canberra Jensen MP, Abreu-Grobois FA, Frydenberg J, Loeschcke V (2006) Microsatellites provide insight into contrasting mating patterns in arribada vs. non-arribada olive ridley sea turtle rookeries. Mol Ecol 15:2567-2575

Jensen MP, FitzSimmons NN, Dutton PH (2013) Molecular genetics of sea turtles. In: Wyneken J, Musick J, Lohman K (eds) The biology of sea turtles, Vol 3. CRC Press, Boca Raton, FL, p 135-161

Kiessling I (2003) Finding solutions: derelict fishing gear and other marine debris in Northern Australia. National Oceans Office, Hobart

> Lee PLM (2008) Molecular ecology of marine turtles: New approaches and future directions. J Exp Mar Biol Ecol 356:25-42

> LeRoux RA, Dutton PH, Abreu-Grobois AF, Lagueux CJ and others (2012) Re-examination of population structure and phylogeography of hawksbill turtles in the Wider Caribbean using longer mtDNA sequences. J Hered 103: 806-820

Limpus CJ (1997) Marine turtle populations of the Southeast Asia and the western Pacific region: distribution and status. In: Noor YR, Lubis IR, Ounsted R, Troeng S, Abdullah A (eds) Proc Workshop Marine Turtle Research and Management in Indonesia. Wetlands International/ PHPA/Environment Australia, Bogor, p 37-73

Limpus CJ (2007) A biological review of Australian marine turtles. 2. Green turtle Chelonia mydas (Linneus). Queensland Environmental Protection Agency, Brisbane. Available at www.austurtle.org.au/SeaTurtleBiology/ green_Linnaeus.pdf

Limpus CJ (2008) A review of Australian marine turtles: 4. Olive ridley turtle (Lepidochelys olivacea). Queensland Environment Protection Agency, Brisbane. Available at www.austurtle.org.au/SeaTurtleBiology/Olive\%20Ridley Escholtz.pdf

López-Castro MC, Rocha-Olivares A (2005) The panmixia paradigm of eastern Pacific olive ridley turtles revised: consequences for their conservation and evolutionary biology. Mol Ecol 14:3325-3334

> Maxwell SM, Breed G, Nickel B, Makanga-Bahouna J and others (2011) Using satellite tracking to optimize protection of long-lived marine species: olive ridley sea turtle conservation in central Africa. PLoS ONE 6:e19905

McMahon CR, Bradshaw CJA, Hays GC (2007) Satellite tracking reveals unusual diving characteristics for a marine reptile, the olive ridley turtle Lepidochelys olivacea. Mar Ecol Prog Ser 329:239-252

> Moore JE, Wallace BP, Lewison RL, Zydelis R, Cox TM, Crowder LB (2009) A review of marine mammal, sea turtle and seabird bycatch in USA fisheries and the role of policy in shaping management. Mar Policy 33:435-451

Moritz C (1994) Defining 'evolutionarily significant units' for conservation. Trends Ecol Evol 9:373-375

Morreale SJ, Plotkin PT, Shaver DJ, Kalb HJ (2007) Adult migration and habitat utilization: ridley turtles in their element. In: Plotkin PT (ed) Biology and conservation of ridley sea turtles. Johns Hopkins University Press, Baltimore, MD, p 213-229

Nei M (1987) Molecular evolutionary genetics. Columbia University Press, New York, NY 
Pfenninger M, Posada D (2002) Phylogeographic history of the land snail Candidula unifasciata (Helicellinae, Stylommatophora): fragmentation, corridor migration, and secondary contact. Evolution 56:1776-1788

Pittard SD (2010) Genetic population structure of the flatback turtle (Natator depressus): a nuclear and mitochondrial DNA analysis. Honours thesis, University of Canberra

Plotkin PT (2007) Olive ridley sea turtle (Lepidochelys olivacea). Five-year review: summary and evaluation. NMFS, Silver Spring, MD and USFWS, Jacksonville, FL

Poiner IR, Harris ANM (1996) Incidental capture, direct mortality and delayed mortality of sea turtles in Australia's northern prawn fishery. Mar Biol 125:813-825

Polovina JJ, Balazs GH, Howell EA, Parker DM, Seki MP, Dutton PH (2004) Forage and migration habitat of loggerhead (Caretta caretta) and olive ridley (Lepidochelys olivacea) sea turtles in the central North Pacific Ocean. Fish Oceanogr 13:36-51

Posada D, Crandall KA (1998) Bioinformatics applications note modeltest: testing the model of DNA substitution. Evolution 14:817-818

Prince RIT, Jensen MP, Oades D, The Bardi Jawi Rangers (2010) Olive ridley turtle presence and nesting records for Western Australia. Mar Turtle Newsl 129:9-11

Pritchard PCH (2007a) Arribadas I have known. In: Plotkin P (ed) Biology and conservation of ridley sea turtles. Johns Hopkins University Press, Baltimore, MD, p 7-21

Pritchard PCH (2007b) Evolutionary relationships. Osteology, morphology and zoogeography of ridley sea turtles. In: Plotkin P (ed) Biology and conservation of ridley sea turtles. Johns Hopkins University Press, Baltimore, MD, p 45-57

Pritchard PCH, Plotkin PT (1995) Olive ridley sea turtle, Lepidochelys olivacea. Status reviews of sea turtles listed under the endangered species act of 1973. National Marine Fisheries Service, St. Petersburg, FL

Shamblin BM, Dodd MG, Bagley DA, Ehrhart LM and others (2011) Genetic structure of the southeastern United States loggerhead turtle nesting aggregation: evidence of additional structure within the peninsular Florida recovery unit. Mar Biol 158:571-587

Shanker K, Ramadevi J, Choudhury BC, Singh L, Aggarwal RK (2004) Phylogeography of olive ridley turtles (Lepidochelys olivacea) on the east coast of India: implications for conservation theory. Mol Ecol 13:1899-1909

Slatkin M (1995) A measure of population subdivision based on microsatellite allele frequencies. Genetics 139:457-462

Swofford DL (2002) PAUP* . Phylogenetic analysis using parsimony ( ${ }^{*}$ and other methods). Version 4. Sinauer Associates, Sunderland, MA

Editorial responsibility: Mark Hamann,

Townsville, Queensland, Australia
Tamura K, Dudley J, Nei M, Kumar S (2007) MEGA4: Molecular Evolutionary Genetics Analysis (MEGA) software version 4.0. Mol Biol Evol 24:1596-1599

- Templeton AR, Crandall KA, Sing CF (1992) A cladistic analysis of phenotype associations with haplotypes inferred from restriction endonuclease mapping and DNA sequence data. III. Cladogram estimation. Genetics 132:619-633

Thompson JD, Higgins DG, Gibson TJ (1994) CLUSTAL W: improving the sensitivity of progressive multiple sequence alignment through sequence weighting, position-specific gap penalties and weight matrix choice. Nucleic Acids Res 22:4673-4680

Thorbjarnarson JB, Platt SG, Khaing ST (2000) Sea turtles in Myanmar: past and present. Mar Turtle Newsl 88: 10-11

Ulaiwi W (1997) Marine turtle research and management in Papua New Guinea. In: Noor YR, Lubis IR, Ounsted R, Troeng S, Abdullah A (eds) Proc Workshop Marine Turtle Research and Management in Indonesia. Wetlands International/PHPA/Environment Australia, Bogor, p 111-120

- Velez-Zuazo X, Ramos WD, Van Dam RP, Diez CE, AbreuGrobois FA, McMillan WO (2008) Dispersal, recruitment and migratory behaviour in a hawksbill sea turtle aggregation. Mol Ecol 17:839-853

White D (2006) Marine debris in Northern Territory waters 2004. WWF Australia, Sydney

Whiting SD, Long JL, Coyne MS (2007a) Migration routes and foraging behaviour of olive ridley turtles Lepidochelys olivacea in northern Australia. Endang Species Res 3:1-9

- Whiting SD, Long JL, Hadden KM, Lauder ADK, Koch AU (2007b) Insights into size, seasonality and biology of a nesting population of the olive ridley turtle in northern Australia. Wildl Res 34:200-210

Wilcox C, Hardesty BD, Sharples R, Griffin DA, Lawson TJ, Gunn R, Rosenberg A (2013) Ghostnet impacts on globally threatened turtles, a spatial risk analysis for northern Australia. Conserv Lett 1:1-8

> Yokoyama Y, Purcell A, Lambeck K, Johnston P (2001) Shore-line reconstruction around Australia during the last glacial maximum and late glacial stage. Quat Int 83-85:9-18

Zaykin DV, Pudovkin AI (1993) Two programs to estimate significance of $\chi^{2}$ values using pseudo-probability tests. J Hered 84:152

Zug GR, Chaloupka M, Balazs GH (2006) Age and growth in olive ridley sea turtles (Lepidochelys olivacea) from the North-central Pacific: a skeletochronological analysis. Mar Ecol 26:1-8

Submitted: January 9, 2013; Accepted: May 27, 2013

Proofs received from author(s): September 6, 2013 